\title{
TOPICAL ISSUES OF FINANCING ELECTRONIC LEGAL PROCEEDINGS IN UKRAINE
}

\author{
Nataliia Kovalenko', lan Bernaziuk ${ }^{2}$
}

\begin{abstract}
The aim of the article is to interrogate and reveal the current issues of financing electronic legal proceedings in Ukraine. The subject of the study is the financing of electronic legal proceedings in Ukraine. Methodology. The study is based on general scientific and special-scientific methods and techniques of scientific knowledge. The historical and legal method enabled to examine the current state of affairs in introducing the system of e-justice, to reveal the concept of e-Court. The comparative legal method enabled to compare the doctrinal approaches to the functioning of the ordinary system of courts and the system of e-justice. The system-structural method contributed to the consideration and identification of the most negative consequences of the delayed implementation of the e-justice system in Ukraine. The methods of grouping and classification were the basis for the author's approach to the identification of possible sources of funding for the e-justice system. The technical legal method enabled to interrogate the state of affairs in electronic legal proceedings in Ukraine and highlight the problematic issues of the practical implementation of this institute, as well as emphasize the need to increase funding for the e-justice system in Ukraine. The results of the study enabled to distinguish problematic issues and ways of their solution in relation to the financing of the e-justice system in Ukraine. Practical implications. In the study, first, the key aspects of introducing the e-justice system in Ukraine are outlined; second, the problems of the practical implementation of the system of e-Courts in Ukraine are highlighted; third, the author's perspective for possible ways of functioning of the e-Court system in Ukraine is substantiated. Relevance/originality. The original author's approach to the current state of affairs in electronic legal proceedings in Ukraine and the practical problems of implementing this institute is the basis for developing the most promising areas for the improvement of domestic legislation in this sphere.
\end{abstract}

Key words: e-justice, court, administrative court, financing, mechanism of financing electronic legal proceedings.

JEL Classification: D73, K23, K41

\section{Introduction}

The information and technology revolution is fundamentally changing the nature and methods of doing business. Using the opportunities of technical exchange makes it easier and faster to create and sell the necessary information, to solve the tasks of financial and operationalmanagement, and mostimportantly, to spend less time on these processes. Definitely, the advantages of the latest information and telecommunication technologies are efficiency, completeness, and reliability of the information necessary to make the decisions that are vital for each of us. Therefore, the study of the topicality of law issues regarding the e-Court and the relevance of its development in Ukraine has a significant role not only for employees in jurisprudence but also for ordinary citizens.

Nowadays, the issue of e-justice is given due consideration in the scientific literature. This issue is studied by A.V.Anisimov, O.R.Arsirii, H.V.Atamanchuk,

Corresponding author:

${ }^{1}$ Judge of Supreme Court of Ukraine, Ukraine.

E-mail: nv417170@gmail.com

${ }^{2}$ Judge of Supreme Court of Ukraine, Ukraine.

E-mail: bernaziuk1979@gmail.com
I. L. Bachylo, V. V. Bilous, O. H. Danylian, V. O. Yeltsov, O. Ye. Simson, O. O. Denysova, R. A. Kaliuzhnyi, N.V.Kushakova-Kostytska,A.I.Marushchak,M.Ya.Sehai, V. P. Kolisnyk, V. S. Tsymbaliuk, V. H. Pylypchuk, M. Ya. Shvets, V. H. Chorna, M. M. Yasynok and others.

Electronic legal proceedings, in particular, were of interest to many domestic scientists, such as V. V. Bilous, M. V. Bondarenko, I. V. Bulhakova, O. V. Holovchenko, A. Yu. Kalamaiko, N. I. Lohinova, A. L. Paskar, L. R. Serdiuk, O. S. Fonova. However, it should be noted that the introduction of information technology resource is studied in its problematic aspects mainly. Therefore, the integrated approach to the introduction of electronic information technology in judicial activities is incomplete.

Therefore, consideration of the doctrinal approaches to the introduction of e-justice in Ukraine becomes relevant and constructs the aim of this article. For its successful achievement, the following tasks should 
be solved: first, to outline the key aspects of financing the system of e-justice in Ukraine; second, to analyse the perspectives available in the specialized literature in relation to the sources of financing e-Court; third, to identify problems of financing electronic judicial proceeding and to propose their potential solutions.

\section{Main material}

Electronic justice is not a phenomenon in world practice. The idea of electronic information traces its origin to the late 80 s of the last century when it became popular and began to operate in countries such as Italy, Canada, the USA, Australia, Switzerland, and many others. Thus, from the very beginnings of e-justice (that is, the 80 s of the last century), the UK government gradually introduced some elements of e-justice, which allowed citizens to become accustomed and to adapt to innovations that were supportive for society because of great facilitation.

Next, the UK carried out the Digital Strategy in 2016; it enables defendants and victims to participate in meetings remotely through online communication. This reformation step has allowed victims and witnesses to take part in court hearings on video communications. According to experts, such simplification helps avoid psychological trauma and allows victims better to recollect the circumstances of the events under consideration.

It is obvious that the novelty needs a legislative basis to regulate relations. Therefore, on December 12, 2003, the UN Declaration "Building the information society: A global challenge in the new millennium" was adopted. The Declaration proclaims important principles of building the Information Society such as the rule of law; transparency policy; favourable competition, based on the principle of technological neutrality, which is provided for by the political and regulatory framework; takes into account the national specificities necessary for the creation of a people-centred Information Society; information and communication technology application and interpretation that should create benefits in all aspects of life; applications, developed on the basis of information and communication technologies, that are significant for public administration bodies' activities and provision of services (Building the information society).

Indicative recommendations for the implementation of democracy in e-justice are set out in Recommendation $\mathrm{CM} / \operatorname{Rec}(2009) 1$ of the Committee of Ministers to member states of 18 February 2009 (Recommendation CM/Rec, 2009).

Recommendation $\operatorname{Rec}(2001) 3$ of the of the Committee of Ministers to the member states on the delivery of court and other legal services to the citizens through the use of new technologies indicates the need to ensure the possibility of: initiating proceedings by electronic means; obtaining information about the state of the proceedings by having access to a court information system; taking further action in the proceedings within an electronic work-flow environment; obtaining the results of the proceedings in electronic form (clause 3 ) (Recommendation Rec, 2001).

The German expert, Dory Reiling, offered an apt fourstage model for benchmarking of electronic interaction between citizens and government:

1) Stage one: Information online about public services;

2) Stage two: Communication/one-way interaction: downloading of forms;

3) Stage three: Communication/two-way interaction: processing of forms (procedural actions in digital form); 4) Stage four: Transaction: case handling, decision and delivery (payment) (Reiling).

Evidently, in the XXI century, electronic information resources have become an integral part of human life, therefore, there is a need to adapt to innovative ideas and step up with the technology.

Ukraine is not an exception, because every year hundreds, and even thousands, of cases in various spheres of justice are considered in our state. Therefore, the e-justice system is an element of e-government, considered today as a way of organizing state power through information networks (Fylonenko, Chorna). So what are the advantages of the e-justice system? First, the e-Court will increase the percentage of public trust in the justice system. Second, it will facilitate the functioning of public authorities and promote the regime of "time saving", simplifying judicial procedures, reducing the term for judicial proceedings and a significant saving of costs.

The e-Court is an online implementation of a number of functions, such as filing a lawsuit, appending it and providing feedback on lawsuits electronically, accessing legal acts, providing "electronic" evidence, reviewing cases online, circulation of information on the current case, functioning of court sites with information on a particular case to the process participants through the Internet or SMS (Kushakova-Kostytska, 2013).

In his monography studying electronic evidence, A. Yu. Kalamaiko highlights that the inadequacy of scientific research of e-justice issues impedes the development of domestic legislation in the area. Consequently, it causes the inconsistency of the current normative framework with the high demands of society, based on the current progress of information and communication technologies. The latter is far ahead of the legislation stage of development. Such a dissonance is one of the factors behind the growth of society's dissatisfaction with the quality of public administration and the quality of the judicial system functioning (Kalamaiko).

The analysis of the approaches conveyed in the scientific literature and the experience of applying the current norms of procedural law of Ukraine testify to the relevance of the study in the area of scientific development of elements of e-justice, such as: 
1) recognition of the full spectrum of existing electronic information resources as valid and completely admissible evidence in the judicial process;

2) the possibility of full two-way communication between the court, the participants in the court process and all other parties concerned through modern electronic information and communication technologies;

3) the possibility of conducting all procedural actions in consideration of any court cases electronically (Kovtun, 2015).

Evidently, information technologies make life easier, open new opportunities. Therefore, justice reforms should not be an exception.

Despite the undeniable advantages of introducing the e-justice institute in Ukraine, the practical implementation of this institute is acutely problematic. Indeed, insufficient financial support impedes the practical implementation of the system.

The Consultative Council of European Judges recognized that the funding of courts is linked to the issue of judges' independence since it determines the conditions in which the courts perform their functions. Moreover, the funding is connected with the administration of the courts, on the one hand, and the principles of the European Convention on Human Rights, on the other hand: access to justice and the right to a fair trial are not properly provided if the case is not considered within a reasonable time by a court, which has the necessary funding and resources to carry out its duties effectively.

All general principles and standards of the Council of Europe regarding the funding and management of courts oblige the states to provide financial resources that meet the needs of various judicial systems. Funding of courts is a part of the state budget, submitted to the Parliament by the Ministry of Finance; such funding should not depend on political instability. Although the funding of the courts, which the state can afford, depends on the political decision, in a system based on the distribution of power, it is also necessary to ensure that neither the executive authorities nor the legislature can bring pressure on the judiciary in determining a budget. Decisions on the allocation of funds for courts should be taken with strict adherence to judicial independence.

In addition to the above-mentioned features of court financing, the issue of financing electronic judicial proceedings includes the costs of implementing an effective and uninterrupted electronic communications system both simple for filing an electronic administrative claim, its directing under the jurisdiction, and for maintaining relevant registries and the open access to them. However, these provisions are complicated and difficult to implement.

The implementation of a large-scale project, "E-Court," enables to solve existing problems in the judicial procedure, such as: 1) ensuring access to justice, since participants of legal proceedings will be able to exchange electronic documents; 2) reducing the costs of issuing paper documents, as well as their mailing to the required court; 3 ) speeding up the exchange of judicial documents between courts and so on.

Electronic justice is key to improving the performance of courts, ensuring transparency and access to court justice and saving public funds (Lohinova).

Ukraine has already tried to introduce the e-Court system in Ukraine in accordance with the Order of the State Judicial Administration of Ukraine No. 72 as of May 31, 2013 "On Implementation of the Project on Electronic Documents Exchange Between the Court and Participants in the Trial”, as amended (On the implementation of the project on the exchange of electronic documents between the court and participants in the trial) by the Order of the SJA of Ukraine No. 81 as of June 14, 2013, which determine the procedure for submitting documents to court in electronic form, as well as sending all procedural documents to the participants in the trial electronically (in parallel with the paper documents). To do this, one should register in the system of exchange of electronic documents between the court and the participants in the process, print the application for obtaining procedural documents in the case electronically, and submit it to the court. This is carried out in civil and criminal cases providing for that a summons letter can be sent through e-mail, fax or telephone or through other means of communication ensuring the fixation of a call.

Recently, on October 3, 2017, the Verkhovna Rada adopted a Draft Law No. 6232 "On Amendments to the Commercial Procedural Code, The Civil Procedural Code, the Code of Administrative Justice of Ukraine and other legal regulations", according to which a Single Judicial Information and Telecommunication System was introduced in Ukraine enabling exchange of electronic documents between all parties to the proceedings and the court, as well as video-streaming of the hearings and participation through a video conference.

Especially, the new regulations consider the modernization of legal proceedings, its electronization and the creation of electronic registries, through which both the court and participants in court proceedings will be able to access information and evidence necessary for the consideration of cases, which should significantly accelerate the resolution of disputes by the court. It should be noted that the evaluation of the adequacy of funding courts does not always depend on formal procedures for consulting or submitting judgments by the judiciary. Direct involvement of courts has always been an important necessity though. It should be noted that the answers to the questionnaire repeatedly revealed many shortcomings: from the lack of necessary material resources (premises, furniture, office equipment, computer equipment, etc.) to the complete lack of assistance needed by judges to ensure 
the modern judicial functioning (qualified staff, special assistants, access to computerized documentation sources, etc.).

It should be noted that in Ukraine, the general lack of budget funds for e-government has led to a decrease in the number of meeting rooms, offices, IT and/or staff (the latter means that judges sometimes have to perform non-judicial functions). One of the problems of financing e-justice is that the judiciary, not always considered as a separate branch of government in the country, has specific needs for fulfilling its tasks and maintaining its independence.

In accordance with the current legal regulations, the centralized procedure for the financing of courts has been established in the State Budget of Ukraine for the current year. Analysing the Budget for 2017, financing of courts increased by $40 \%$. This is a positive change. According to 2017 reform, financing of the courts shall be agreed with the High Council of Justice, which has not been formed yet. Meanwhile, the High Council of Justice will carry out its duties at least until 2019, according to experts' forecasts. To date, the Constitutional Court of Ukraine, the Supreme Court of Ukraine, the highest specialized courts, and the State Judicial Administration administer state funds for the maintenance of courts.

A practical scheme was also implemented to follow the mechanism of the future judicial telecommunication system. In accordance with the Order of the State Judicial Administration No. 367 as of March 23, 2017, since April 01, 2017, in seven pilot Ukrainian courts, the Temporary Regulation of electronic documents exchange has been introduced. For example, along with the positive practice of introducing e-justice, the Zhovtnevyi District Court of Odesa and Vinnytsia District Administrative Courts may already indicate shortages and necessary revisions of the E-Court regulatory framework.

The pilot project "E-Court in the Kyiv District Court of Odesa" can be an example. The first steps of electronic interaction were made between the two institutions, the Kyiv District Court of Odesa and the Odesa Research Institute for Forensic Examination of the MJU. Initially, it was the sending of applications electronically, followed by an additional corresponding paper copy that allowed saving 3-4 days on the exchange of documents and laid the foundation for establishing a dialogue.

The abovementioned process enabled to avoid sending paper copies of documents, consequently, to save both time and budget funds (no need to spend money on resending the letter, going to post offices, and waiting in meter queues). Therefore, the initial stage of the interaction between the institutions achieved significant results: the reduction of the forensic examination period, the improvement of efficiency of interaction between the institutions, and faster resolving of the court proceedings of participants' disputes (Chvankin).
It is difficult to overestimate the prospects for the further development of judicial institutions. Evidently, through electronic communications, it will be possible to send requests, answers, advisory materials, materials of cases for conducting expert research in the shortest period.

The final and transitional provisions of the Draft Law No. 6232 "On Amendments to the Commercial Procedural Code, the Civil Procedural Code, the Code of Administrative Legal Proceedings of Ukraine and other legislative acts" provide for that the transfer of proceedings to the e-Court will occur gradually. Cases initiated by materials in paper form prior to the operation of the Single Judicial Information and Telecommunication System and not yet completed should be considered in paper form. The participants in the proceedings still have the right to submit paper documents to the court after the introduction of the e-Court system.

The novelty is the introduction of electronic evidence, that is, electronic (digital) information that contains circumstances relevant to the case, including electronic documents (text files, graphic images, photographs, video and audio), the websites (pages), text, multimedia, and voice messages. They can be stored in backup systems, other places of electronic data storage, including Internet resources. Electronic evidence is filed in the original or in electronic copy, certified by an electronic digital signature. The Draft Law also contains innovations regarding the registration and issuance of executive documents: they are represented in electronic form using the Single Judicial Information and Telecommunication System and are signed by an electronic digital signature of the judge. Within 5 days after the court judgment is enforced, the enforcement document is submitted to the Unified State Register of Executive Documents, and its copy is sent to the payee at its official e-mail address, or by a registered or certified letter (Hrishyna).

The reform is inspired by the state intention to build a people-centred, open, and aimed at the development Information Society, which provides everyone with free access to the use and exchange of information by exercising their right to free access to information and raising the quality of life (Pro Osnovni zasady rozvytku informatsiynoho suspilstva v Ukraini, 2017).

However, effective functioning of the system provided by the Law No. 6232 needs interrelation of the proper economic and financial support of the e-Court and the human factor. Considering in total, the e-Court is an undeniably qualitatively new and promising process. Nevertheless, some questions exist. In Kyiv and other regional centres, technological innovation problems should not arise. What about small towns and villages? There the courts lack the human resources to ensure quality and fast legal proceedings in paper form, process participants cannot receive court decisions for months, so prospects for e-justice seem out of reach. 
Along with the advantages regarding the introduction of the e-Court and the reduction in the corruption component by removing direct contacts between the court process participants, third-party interference with the e-justice system is possible. In the era of information technology, the access of key process participants (judges) to e-justice must be protected from the influence of third parties at the highest level. Moreover, uninterrupted access of all process participants to the e-Court should be ensured so that such key principles of justice as publicity and openness of the trial are in no way impaired due to technical malfunctions of the system (Roik).

\section{Conclusions}

Therefore, e-justice as one of the sectors ofe-government is a safe area of development on the way of forming a new information society (Roik). With conviction, e-Court has many advantages. First, it can save time considerably. The exchange of documents is more reliable and operative. Second, it provides operational access to the materials of the case. Some situations require receiving or transmitting urgently a certain document that the materials of the case contain. For now, an appropriate application should be written, which often takes weeks. Third, there is no need for certifying copies of documents. Electronic legal proceedings enable to avoid the time costs of producing paper copies of documents, and the recipient of such a document will always receive an exact copy, the validity of which can be verified through the data of the telecommunication system. Therefore, the Ukrainian judicial system is ready to introduce a meaningful e-Court. However, the introduction of such technologies should be backed up by the relevant legal regulations in the legal sphere.

At the same time, it should be emphasized that the management of budget funds allocated to courts for the implementation of the e-justice system implies more and more responsibility and needs a professional approach. The systems controlled by judicial authorities or by persons or by a body accountable to the judiciary or an independent body with the necessary administrative support differ noticeably from the systems, in which the government unit or service is fully responsible for management. The state should review existing procedures for the financing and management of electronic legal proceedings. In particular, the necessary resources should be provided to the e-Court system in order to enable it to function in accordance with national and international standards.

\section{References:}

Building the information society: A global challenge in the new millennium (Declaration). Retrieved from: http://zakon5.rada.gov.ua/laws/show9995_c57

Recommendation CM/Rec (2009). Committee of Ministers to member states. Retrieved from: http://www.coe.int/ t/dgap/

Recommendation Rec (2001). Committee of Ministers to the member states on the delivery of court and other legal services to the citizens through the use of new technologies. Retrieved from: http://sc.gov.ua/uploads/tinymce/files/

Reiling, D. Informatsionnye tekhnologii v sudakh Yevropy: mneniia, praktika i innovatsii [Information technology in European courts: opinions, practices and innovations]. Retrieved from: http://home.hccnet.nl/a.d.reiling/ html/Information

Kushakova-Kostytska, N. V. (2013). Rozvytok elektronnoho sudochynstva v Ukraini: problemni pytannia [Development of e-justice in Ukraine: Problematic issues]. Naukovo-informatsiinyi visnyk. Pravo, 7, 139. (in Ukrainian) Kalamaiko, A. Yu. Elektronni zasoby dokazuvannia $v$ tsyvilnomu protsesi [Electronic means of proof in the civil process]. Retrieved from: http://nauka.nlu.edu.ua/download/diss/Kalamaiko/d_Kalamaiko.pdf (in Ukrainian)

Kovtun, M. (2015). Elektronnyy sud: pryzvychaimosia do novatsii [E-Court: Let's Get Started with Innovations]. Visnyk Natsionalnoi asotsiatsii advokativ Ukrainy, 5, 51. (in Ukrainian)

Lohinova, N. I. Uprovadzhennia elektronnoho pravosuddia v systemu sudochynstva [Implementation of e-justice in the system of legal proceedings]. Retrieved from: http://www.apdp.in.ua/v72/61

On the implementation of the project on the exchange of electronic documents between the court and participants in the trial. Retrieved from: http://zib.com.ua/ua/21310-nakaz_dsa_ukraini_72_vid_31052013r.html

Chvankin, S. A. Pro elektronnyi sud [On e-Court]. Retrieved from: http://zib.com.ua

Hrishyna, N. «Elektronnyy sud» - sproshchennia dostupu do pravosuddia ["Electronic Court": Simplification of access to justice]. Yurydychna hazeta. Retrieved from: http://yur-gazeta.com/publications/actual/elektronniysud--sproshchennya-dostupu-do-pravosuddya.html (in Ukrainian)

Pro Osnovni zasady rozvytku informatsiynoho suspilstva v Ukraini (2017). [On the Basic Principles of the Development of the Information Society in Ukraine] (Law of Ukraine). Vidomosti Verkhovnoi Rady Ukrainy, 12, 102. (in Ukrainian)

Roik, O. Ukrainska Pravda [Ukrainian Truth]. Retrieved from: http://yur-gazeta.com/.html (in Ukrainian)

Bilous, V. V. Innovatsiini napriamky informatyzatsii sudochynstva [Innovative areas of informatization of legal proceedings]. Retrieved from: http://www.nbuv.gov.ua/ (in Ukrainian)

Fylonenko, V. V., Chorna, V. H. Perevahy zaprovadzhennia elektronnoho sudochynstva v Ukraini [Advantages of introducing e-justice in Ukraine]. Retrieved from: https://www.naiau.kiev.ua/files/kafedru/app/KS_2018.pdf\#page=90 